\title{
A Practical Study of the Cultivation of Innovative Foreign Language Talents in Colleges and Universities"
}

\author{
Yuan Kong \\ School of Foreign Languages, Jining Medical University, Jining, China
}

\begin{abstract}
The cultivation of foreign language innovation talents must start from its concept. First of all, it is necessary to accurately understand the core concepts of innovation talents, foreign language innovation talents and innovative talent cultivation practice. The cultivation of innovative foreign language talent is a holistic design. It is the overall orientation and guidance of thought and spirit. It involves education theory, innovation theory, and talent development concepts. These categories boil down to basic theory and basic principles. Colleges and universities use this theory and principles as the basis, innovate in organizing various teaching elements to achieve the goal of cultivating foreign language creative talents. The cultivation of foreign language innovation talents is not composed of a single concept. In order to do a good job in cultivating foreign language innovative talents, we must accurately define the important concepts it includes. This article aims to cultivate the necessary foreign language talents for social development. It tries to integrate innovation training theory into talent education and eventually puts it into teaching practice.
\end{abstract}

Index Terms - innovative Foreign language talents, comprehensive quality, practical research

\section{INTRODUCTION}

With frequent cultural exchanges and changes in social needs, many countries are aware of the importance of the cultivation of innovative foreign language personnel. Domestically, there are also distinctive features in the cultivation of foreign language innovative talents. Some universities, research institutes, and foreign language experts have long recognized the importance and urgency of cultivating foreign language innovation talents. In particular, some foreign language research universities make use of good opportunities. Based on their understanding of foreign language innovation talents and their own objective conditions, they have learned from the successful experiences of foreign countries and adopted distinctive innovation training models. The emphasis is on both liberal arts and sciences, emphasizing the direction of scientific research in the cultivation of foreign language innovation talents, adopting a multidisciplinary model, and suggesting that foreign language teaching should be forward-looking and that teachers of applied disciplines should be taught to foreign language students.

Judging from the current status of our country's teaching practice, the basic theory of the cultivation of foreign language innovative talents has been recognized by domestic universities and has become one of the teaching goals for the development of domestic colleges and professional foreign language colleges in the future. Although foreign and domestic foreign language research scholars have made achievements, they have effectively promoted the construction of a practical system for the cultivation of foreign language innovation talents. However, from the existing foreign language teaching practice, there are still some problems and deficiencies. Moreover, with the development of the times, general education has become an important part of the cultivation of innovative foreign language personnel.

\section{Foreign LANGUAGE INNOVATION TALENTS}

The connotation of foreign language innovation talents is talents with innovative abilities in foreign language majors. Innovative foreign language talents have a good foundation in foreign language studies and have a deep understanding and mastery of the cultural background knowledge of the foreign languages they possess. They usually have knowledge and skill systems that include multiple disciplines, and can integrate professional subject knowledge and foreign language knowledge into one. Innovative thinking can deal with possible work problems with traditional and innovative work methods, and it has strong competitiveness after entering the society (Huang \& Huang, 2016). Foreign language innovation talents have the following distinctive features: solid foreign language knowledge and application skills,

\footnotetext{
* Funding Sources: Social Science Planning Research Program of Shandong Province (Grant No. 17CWZJ38); Scientific Research Program of Colleges and Universities in Shandong Province (Grant No. J17RA054); Research Program of Young Teachers' Education and Teaching of Shandong Province (Grant No. 16SDJ232); Key Program in Art Science of Shandong Province (Grant No. ZX2015005); Youth and Adolescents Quality Education Work Planning Program of Shandong Province (Grant No. 13AJY090); Scientific Research Program of Jining Medical Univ ersity (Grant No. JY2013RW032); The Visiting Scholar Funded Program of Young Backbone Teachers in Jining Medical University; College Students' Inno vative Training Project of Jining Medical University (Grant No. cx2017052); Scientific Research Project of College Students in Jining Medical University (Grant No. JYXS2017RW017)
} 
careful logic judgment ability, and success beliefs. The composition of the knowledge system is not limited to the multiple majors of the foreign language major itself, and it has a sufficient level. The open way of thinking judgment is firm, and it extends to multiple professions related to the application of foreign languages, and has a sufficient level.

\section{Research Status of Foreign LANGuage InNOvation TAlent AT Home And AbroAd}

With frequent cultural exchanges and changes in social needs, many countries are aware of the importance of the cultivation of innovative foreign language personnel. Nowadays, foreign institutions have made different experimental attempts to cultivate foreign language innovative talents based on their own understanding and objective conditions, and have achieved good results. The cultivation of foreign language innovation talents in the United States started from research universities. These schools use research centers and professional laboratories as training units, emphasize the cooperation between departments and colleges, and form joint training groups, stressing the cultivation of foreign language innovative talents in an interdisciplinary background $(\mathrm{Li}, 2011)$. In order to achieve the purpose of strong alliances, training characteristics is quick and takes up less resources. Different from the United States, the United Kingdom put the starting point into the daily foreign language teaching classroom, and gradually cultivated the innovation of foreign language talent through the setting of courses. Germany, as a powerful education country, starts from the application practice and provides students with a large number of opportunities in business practice, and takes the needs of the enterprise as the direction of teaching. In the foreign language course, the content of subjects such as philosophy, psychology, mechanics, etc. was added. The two countries have cultivated foreign language innovative talents from the perspective of academic research. They hope that they will inspire innovation in foreign language talent through research work. Some universities and foreign language schools in Japan have no longer taught individual subjects in foreign languages (Liu, 2015). Instead, they combine foreign language subjects with other subjects to form a unified subject teaching group. Adopt flexible teaching and use industrialized models to cultivate foreign language innovation talents that meet the requirements of Japanese society. Japan attaches great importance to practicality in the cultivation of foreign language innovation talents, emphasizing the cultivation of foreign language innovation talents based on the needs of society. It can be seen from the above that foreign universities and colleges are based on the actual conditions and needs of their own countries in the cultivation of foreign language innovation talents and adopt a joint training model, emphasizing the importance of practical teaching.

Domestically, there are also distinctive features in the cultivation of foreign language innovative talents. Some universities, research institutes, and foreign language experts have long recognized the importance and urgency of cultivating foreign language innovation talents (Mao \& Wang, 2011). In particular, some foreign language research universities make use of good opportunities. Based on their understanding of foreign language innovation talents and their own objective conditions, they have learned from the successful experiences of foreign countries and adopted distinctive innovation training models. The emphasis is on both liberal arts and sciences, emphasizing the direction of scientific research in the cultivation of foreign language innovation talents, adopting a multidisciplinary model, and suggesting that foreign language teaching should be forward-looking and that teachers of applied disciplines should be taught to foreign language students. Some colleges and universities have taken the lead in trying to break the long-term foreign language education in the cultivation of foreign language students in our country has paid too much attention to the current situation of foreign language learning, increase natural science courses, use fresh and lively subject knowledge to stimulate students' brain cells. This approach is consistent with the evolution of foreign languages as a language itself. The results of educational practice have also cultivated many foreign language professionals with innovative qualities. In the practice of training foreign language innovative talents, some universities have achieved very good results. For example, Shandong University has introduced a new foreign language training model of "Foreign English + X", which is characterized by multidisciplinary knowledge teaching (Niu \& Lu, 2015). It focuses on foreign language subjects and related applied disciplines, integrates teaching resources of multiple disciplines, and adopts a five-year system. The double-degree class has achieved outstanding results. The overall quality of students is obviously improved, and they are more willing to play their unique views. They can often produce innovative ways of thinking and dare to translate actual learning into concrete behaviors in social practice. Some province-level colleges and universities in Shandong Province believe that a comprehensive training model should be adopted at the basic teaching stage, stressing that foreign language innovative talents need to have two basic qualities, namely critical thinking ability and logical reasoning ability. We hope to use a specialized and innovative team of teachers to promote teaching and develop innovative foreign language teaching practices in the context of professional competence.

Judging from the current status of our country's teaching practice, the basic theory of the cultivation of foreign language innovative talents has been recognized by domestic universities and has become one of the teaching goals for the development of domestic colleges and professional foreign language colleges in the future.

\section{Practical Exploration of InNOVATIVE Foreign Language Talents}

From the perspective of the history of teaching reform, a foreign language school of a medical university has a relatively clear understanding of foreign language personnel training. It is specifically reflected in the formulation of teaching goals and has always kept pace with changes in society's demand for foreign language professionals. 
According to the new requirements of the society for foreign language talents, new content is added to the syllabus. Especially in recent years, the demand for innovative talents in foreign languages has been increasing (Sun \& Liu, 2013). The School of Foreign Languages recognizes the era and importance of the cultivation of innovative foreign language talents.

From the teaching practice point of view, schools and foreign language colleges have joined the relevant content of foreign language innovation talents in the formulation of the annual talent training program, and clearly put forward encouragement and cultivation of innovative spirit and innovation ability, and improve the training and cultivation of students' innovative thinking ability. Although the Foreign Language Institute has made efforts in the cultivation of foreign language innovation talents, the effect has also been affirmed. However, the concept of innovative talents is still not clear, there are no explicit guiding opinions, and there is no clear explanation for the concept of innovation consciousness (Wang, 2017). The College of Foreign Languages implements a credit system and stipulates total credits for foreign language students. In addition to compulsory courses, there are a large number of elective courses and reforms of current teaching. Although the current teaching content is still dominated by foreign language and literature, it also increases the content of foreign language application disciplines. The instructors are professional teachers. It also cooperates with the three colleges of law, management, and economics, allowing foreign language students to study courses at three colleges, and the credits they receive are directly credited to the total credits. Students are exposed to knowledge related to foreign language applications outside of this major. Although it cooperates with disciplines, the curriculum is still relatively small and cannot fully meet the needs of students (Wang \& Ma, 2014). From the perspective of the breadth of knowledge, it is still relatively limited and the number of disciplines is small.

In the talent training program, it is clearly stated that the cultivation orientation of foreign language students includes education, economics, trade, foreign affairs, culture, science and technology, knowledge of economy, trade, and science and technology, and the formation of innovative thinking, clearly points out that we must have modern consciousness, and we must cultivate students' innovative spirit. Such as English majors, teaching content includes an introduction to linguistics, an overview of English and American countries, English literature, American literature, translation, interpretation, and cross-cultural communication. The Russian language professional has Russian national conditions, Russian literary history and selected works. Japanese language majors have an introduction to Japanese and Japanese literary works. To selected readings of DPRK literary works in Korea, Korean society and culture, history of Korean literature (Xia, 2015). In order to enrich students' knowledge system and expand their horizons, data analysis theory and information retrieval contents have been added to elective courses. Although the latest talent plan partially embodies the concept of cultivating innovative talents in the teaching and training program, it involves few applied subjects, and the content of humanistic knowledge is still insufficient. This objectively limits the cultivation of students' innovative ability and easily eliminates students' Innovation enthusiasm.

With regard to the teaching system, starting from the actual conditions of schools and colleges, it provides students with better facilities for innovative practice activities. Specific measures include encouraging students to participate in various types of academic activities. In order to better ensure the participation of students, they must make rigid rules. At the end of each academic year, students are required to write their own academic results and participate in assessments. This assessment is credited to the final student file. For students' original academic works, the literature is affirmed from the school's point of view, and special "innovation credits" can be obtained, which is equivalent to obtaining the same credits as elective courses, and is included in the total credits. The curriculum is designed to draw on the success of other foreign language schools in China, set up a wide range of foreign language applications, and arrange for students to participate in the annual extracurricular practice. However, for students with low creative credits, objectively it will affect the students' enthusiasm for innovation. In the evaluation of innovation, there is still a lack of scientific means. From the actual operation, we still use the regular examination plus some subjective evaluation models, and there is a certain gap between the objective requirements of foreign language innovation talents (Xie \& Chang, 2013).

Pay attention to the construction of a practical base. The practice of foreign language students is divided into two parts, intramural and out of school. The College of Foreign Languages arranges students to conduct teaching practice at a practical base for each semester. The time for internships is fixed so that students can test knowledge and have innovative results in practical situations. The content of practice is rich, such as work translation, office clerk, product introduction, industrial product sales, etc. Students can choose according to their own preferences and development needs. Appropriate rewards are given to those who perform well, such as providing opportunities for foreign companies to serve as interns. All of these have inspired the creative expansion of student thinking to some extent (Xie \& Wu, 2013). However, the number of places and posts for internships is still low, and the time for internships is too tight. There are not many internship companies outside the university. They cannot fully meet the needs of students.

School of foreign languages has made many attempts and exploration in cultivating innovative talents, to innovative ideas and innovative spirit mentioned hitherto unknown height and write the personnel training programs, develop, teaching objectives in the curriculum, teaching system, base construction and other aspects have done a lot of work. However, there are still many unsatisfactory places for the cultivation of foreign language innovative talents, and there are still problems to be solved in many aspects. 


\section{Foreign Language InNovative Talents Training Program}

\section{A. Teaching Objectives}

1. Subject application ability

Emphasizing the application ability of disciplines, according to the requirements of College English curriculum requirements issued by the Ministry of education and the current needs of foreign language majors, we can think that the essence of foreign language teaching at present is giving students foreign language knowledge and mastering them. Only based on the premise of language application, foreign language teaching is meaningful and truly plays the communicative role of the foreign language itself. It is necessary to improve the quality of foreign language students in all aspects and must break through the limitations of the existing foreign language disciplines. The school of foreign languages should reconsider the orientation of foreign language teaching. Foreign language teaching is no longer confined to the Foreign Language Institute itself. Instead, it should expand to all schools and majors related to foreign languages, and enrich students' knowledge structure. Let the language and knowledge integration, according to the characteristics of foreign language majors, the teaching plan to re-evaluate existing construction, formed in the foreign language study as the foundation, professional skills and disciplines knowledge to complete teaching system and supplement, classroom teaching and extra-curricular learning combined, teachers guide students according to the need of study and their own ideas and development goals to multi-level teaching system. According to foreign language students today's employment wide broad, pay attention to expand students' knowledge and vision, more from the social practice perspective on the importance of learning a foreign language and practical significance, the students from the original foreign language learning into the social practice, to meet the objective needs of society for talents, deepening the understanding of the students foreign language learning itself.

2. Learning concept

It is necessary for students to set up a learning idea to learn to use. Foreign language teaching is not only the imparting of the content of foreign language knowledge. From the perspective of the application of foreign languages, foreign language learning is based on the application of the subject. The language content of the foreign language is covered with the content of the specialized subject, and the information exchange between different language groups is realized. Expand the number and type of students' extracurricular reading materials. According to professional requirements and student preferences, the school year is used as a unit to formulate a range of reading books for students after class, from low to high difficulty foreign language professional books, famous literary works in China and foreign countries, and culture-related classics of various countries. Books, etc., through reading exercises, integrate foreign language and professional knowledge learning into the construction of students' knowledge systems, and at the same time pay attention to the cultivation of students' own character qualities.

3. Breadth of knowledge

Broadening the students' knowledge breadth is a necessary measure for foreign language majors. One of the conditions of innovative talents is that they have enough knowledge and breadth for the world. The knowledge that students possess must meet the needs of society in a wide range, which is also an important quality of diverse social needs. With the continuous deepening China exchange with the world level, in the process of innovative foreign language talents, pay attention to help students to broaden their horizons, cultivate students' cross-cultural awareness and international communication ability, and innovative international thinking ability, some foreign cultural knowledge reserves, familiar with the customs of different peoples and cultural characteristics respect each other's customs in the process of communication with other nations, a reasonable deal with problems. In the process of international affairs, the students are trained with keen social observability, skillful means of transnational communication and good judgment of active thinking. In the course of school learning, the human resources of the school, the system structure of the school and the knowledge resources of the teachers can be maximized. Therefore, on the premise of cultivating students of foreign language learning foreign language skills, to ensure a comprehensive development of many aspects of students' moral, mental and physical health, especially in foreign language related disciplines more professional knowledge, to effectively improve the students with professional knowledge in the field of contact surface, broaden the students to society cognition, strive to become the compound and practical talents. Strengthen the cultivation of students' humanistic quality. Teachers are not only the imparting knowledge, but also the students' understanding of foreign language learning and the deep understanding of the foreign language learning itself. The importance of humanistic quality is not only to enrich students' knowledge, but also to have the mental quality of a healthy life. In this way, in the complex and complex social environment, the quality of innovation can be successfully turned into results, and the successful transformation of ideas and applications can be realized.

\section{B. Teaching Content}

\section{Innovation spirit}

In the teaching of cultivating innovative foreign language talents, the cultivation of innovative spirit must be embodied. The spirit of innovation is the ideological consciousness of the individual, which comes from the students' active behavior to knowledge, and is influenced and restricted by the subjective thinking ability of the people. The ability of active thinking is the direct source of innovation. Only students with the ability of active thinking can burst the spark of inspiration. The training of students' active thinking ability begins with imitation. Study and analysis of 
problems imitated when facing problems and problem solving ideas, ideas change the past one-way teachers impart knowledge to teaching methods of students, students should be regarded as equal subjects in the teaching process, students participating in the teaching organization give opportunity to activate the vitality of classroom teaching, stimulate the creativity of students, so foreign language teaching has become a true two-way circulation of knowledge imparting behavior. The training of students' active thinking ability begins with the analysis of the problem. The problem is divided into two types: the analysis of the problem and the problem solving. Analyzing problems refers to students' consideration of problems through objective analysis, understanding of the nature of things or phenomena, or the nature of internal relations between certain things or phenomena. Such problems will encourage students to think in different ways, such as comparison, relevance, logic, and organized ways. The problem of solving the problem is to respond by creative thinking activity on the basis of hypothesis, objective analysis, reconstruction, and the needs of subjective imagination. In this way, students not only learn to use definitions and rules, but also produce evaluation, abstraction, prediction, and imagination, which is a specific and systematic process. In classroom language communication activities, we can concentrate on evaluative analysis questions, so as to activate students' original knowledge and experience reserves and facilitate learning of new knowledge. In reading teaching, we can choose more ways to solve problems and guide students to form complex and holistic thinking habits to solve problems.

2. Innovation consciousness

The consciousness of innovation is the individual characteristic of human being, it is the logical mode of thinking that solidified in the mind, and it is gradually formed in the practice of subjective consciousness. The cultivation of innovative consciousness should start from teaching, start from scratch, and lay a solid teaching strategy according to the characteristics of foreign language learning, focusing on the work of foreign language teaching. According to the maturity of human psychology, the intelligence of college students is the most active time in human life, and psychology is also moving towards maturity. This is the key period for the gradual establishment of abstract thinking. The traditional one-way language training model can not fully meet the psychological demands of college students. The challenging, difficult and logical discussion and analysis teaching model is the most suitable for the development of college students. Therefore, according to the characteristics of the psychological development of college students, the content of research is added in the teaching of foreign languages, the difficulty and depth of foreign language teaching are improved, the problem of "with" purpose is set for the students, and the senses of the students are mobilized. In order to guide students to master, explore and establish a learning mode with personal tags. In this way, we can not only save teaching resources, but also enable foreign language teachers to introduce the content of applied disciplines from the perspective of comprehensive quality development, so as to improve the depth and efficiency of foreign language teaching.

3. Knowledge content

The combination of the existing foreign language teaching and applied disciplines is relatively small, which is not conducive to the integrity of students' own knowledge system and limits the scope of innovation consciousness and strategy. Therefore, it is necessary to enrich the knowledge of applied subjects and develop interdisciplinary teaching. Drawing lessons from the experience gained at home and abroad and the status of applied disciplines in a medical university, medical courses such as nursing and mental health are closely introduced into the teaching arrangement and are closely related to the current foreign language major. Teachers are hired to attend classes, which are organized in the form of seminars, seminars, and joint training. This kind of interdisciplinary training method has achieved good results both in domestic and foreign practice, and it also meets the practical needs of foreign language innovation personnel training.

Interdisciplinary training is not a simple introduction to new curriculum content, but a higher starting point to guide foreign language teaching. Using ESP and other task type teaching methods, we absorb and learn the thinking concepts and learning methods of applied disciplines, draw lessons from the research mode, stimulate students' curiosity and curiosity for new things. In the process of interdisciplinary learning, students accept two disciplines knowledge teaching, which is helpful to stimulate students' learning potential and guide students' innovative ability from multiple perspectives.

\section{Teaching Practice Model}

\section{Practice base}

The purpose of practice is to test students' innovative learning outcomes and provide students with innovative thinking platform. Therefore, colleges and universities should increase practice base for practice according to the requirements of foreign language majors and construction needs. The construction of the practice base is the fundamental guarantee. Only innovation through practice can be a real innovation. Therefore, based on the combination of existing practice bases, improve and add new practice bases. Establish a system of responsible persons for practice. The leadership of the external institute is responsible for the practical work within the language profession. According to the teaching laws of foreign language majors, according to the track of the growth of talents, establish a practice base that meets different stages. The establishment of an off-campus training and training base can actively cooperate with enterprises. The practice base must participate in the substantive operation stage. Students have planned interns in various units during the summer and winter vacations. Every practice base has a foreign language professional tutor, and a student's practice tracking inspection and appraisal conclusion (Zhuang, 2012). Practice teaching will inspire 
teachers to pay attention to the reform of classroom teaching. The construction of practice training base can combine the training of innovative talents with the actual needs through the way of employment channel, and form a benign interaction.

\section{Content of practice}

Practice is the sole criterion for testing truth, and the cultivation of foreign language innovation talents is also included. To refine the content of the practice, such as the English language professional for the United States, Britain and other English-speaking countries, translation, technical translation and other posts. The practical content of students must be based on the real language environment. Teaching management departments and colleges should meet students' practical requirements and guide students in the campus environment to feel the same working atmosphere as society. According to the characteristics of the students, the conditions of the school's teaching resources, and the future development trends, a reasonable and practical approach should be established. Provide a variety of forms of practical communication. Such as foreign language debate games, speech contests, foreign language film dubbing competitions. By combining the interests of students, students are strongly concerned. At the same time, it allows students participating in the study to truly understand the characteristics of foreign language practice exchanges.

3. Inspection of results

Contemporary college students have a strong sense of autonomy and are willing to try new ideas and practice. However, only the tested learning results can guide students to follow the correct road. The college can rely on this favorable condition to encourage students to carry out independent innovation practices and enrich the specific forms of innovation and practice activities. Monotonous practice behaviors can easily lead to psychological fatigue and affect the effectiveness of innovative teaching. Therefore, it is necessary to enrich the forms of innovation and practice activities. Students' subjective initiative should be brought into play and students should be encouraged to create and participate in various types of innovative practical activities according to their interests, hobbies and ideas. For example, foreign language debates, dramas, speeches, etc. are held. Such self-innovation actual behavior can stimulate students' potential, honing their will, and stimulating the active thinking cells in the brain. In the actual application process, it is of great benefit to improve the overall quality of students. In addition to students' proactive behavior, advanced teaching methods can also be adopted to guide students' independent innovation. Reproduce through specific scenarios to create a scene of perceptual knowledge and knowledge. If you can establish a business communication scene, teachers can use some pictures, charts, and some examples to help students obtain customer information and learn communication methods. Teachers can also obtain information from other websites, allowing students to browse the company's website, including product pictures and samples, and then collect information such as credit status, product variety, transaction scope, etc. to summarize and compare, and select the appropriate partner company. Allow students to analyze and propose improvements. Finally, the student completes the establishment of the business relationship based on the selected information. During the entire process, the teacher is only responsible for setting up the situation. Solving the problem is left to the student to handle the problem.

\section{Guarantee System of Teaching System}

\section{Foreign language teachers}

Foreign language teachers are the direct executors, leaders, and witnesses of the cultivation of foreign language innovation talents. With superb professional quality and ideological quality, fully recognizing the history and practical significance of the cultivation of foreign language innovation talents is an important guarantee for the cultivation of foreign language innovative talents. The cultivation of foreign language innovative talents requires a team of teachers that meets the requirements of innovation, that is, the establishment of a team of foreign language teachers with knowledge of applied subjects. The specific approach may be to improve the professional quality of teachers through a variety of practical and effective forms, such as professional training, professional training, special seminars and academic reports. The introduction of fresh blood and the recruitment of talents will help young and middle-aged talents with innovative consciousness to teach in schools and enrich their foreign language teachers. It is also possible to learn the successful experience of the college. At the same time, we should improve the existing teacher management system, set up a post standard for teachers, select qualified teachers to teach, encourage foreign language teachers to actively improve their teaching skills and enhance their professional quality. The introduction of the annual talent introduction plan enriches the new foreign language teachers to the existing teachers. We should also set up regular teachers' technical training classes to improve the overall teaching level of foreign language teachers in the short term.

\section{Teaching management department}

The cultivation of foreign language innovation talents is not a one-time, it is a difficult practice process. The Department of Teaching Management should work together to ensure that this important teaching work can be carried out smoothly. Create a good atmosphere and do material protection. School-level innovation talents training awards and outstanding innovation talents awards have been established. Students and teachers in the field of innovative talent cultivation have been given material and spiritual rewards. Incentives are the driving force for teachers and students to advance in foreign language innovation. The student assistantship system and the student representative system can also be adopted. The student assistantship system can effectively reduce the work burden, and let the teachers put more energy on how to improve the students' ability to think on the initiative. As a teaching assistant, students can enter the student's foreign language learning with the student's special identity, and continue the classroom teaching to daily life, 
forming a real-time unification of class and class learning. The student representative system is to choose a representative student with outstanding foreign language ability. Though them we may understand the students' problems in foreign language learning and the characteristics of their thinking. It can help teachers to better inspire students, guide students to form a personality of foreign language learning model, guide students to exercise independently, active test and improvement. It can be seen from this that teaching management departments should fully implement the two systems, provide better treatment for the students who are in charge, set up the typical models of students, and promote the reform of foreign language teaching aiming at innovative training.

3. Teaching quality evaluation

The evaluation of teaching quality is an effective way for foreign language teachers to understand the courses taught and grasp teaching information, as well as an accurate reference for students' self adjustment and improvement. The starting point of teaching management department should be the training principles of innovative talents in foreign languages, the scientific setting of teaching quality evaluation criteria, and accurate comprehensive consideration of foreign language teachers, curriculum settings and student learning effects. The motivation of human behavior is to look at the training of foreign language innovative talents. The positive motivation of teachers is the intrinsic motivation of improving the talent cultivation rate of foreign language talents (Zhuang \& Liu, 2012). A lot of practices have already shown that external pressure has an unpredictable impact on Teachers' work enthusiasm, and often leads to opposite results, which hinders teachers' enthusiasm and is not conducive to the development of innovative talents' teaching. Therefore, in the traditional delete biased assessment of the contents of the evaluation of teaching quality, starting from the perspective of improving teachers' enthusiasm, to create a good working environment for foreign language teaching, to promote the current foreign language teaching reform, help teachers to recognize the problems in teaching, to guide the learning of advanced teaching methods and teaching ideas, will enhance the cultivation of foreign language talents as a fundamental purpose.

4. Student achievement assessment

The assessment of student achievement should be based on the actual situation of teaching, the characteristics and development requirements of students, especially the regularity of foreign language innovative talents, so as to establish a scientific assessment system. Get rid of the single score standard, take full account of the individual differences of the students, and realize the diversification of the assessment means, scientific and rational. On the content standard of student achievement evaluation, besides traditional scores, we should add professional skills, professional knowledge, innovative ability and problem-solving ability to achieve a more comprehensive performance evaluation. The subject of evaluation should also be diversified. It can choose teachers, practice experts and select students, so as to analyze and comment on students from multiple perspectives. The methods of evaluation are also diversified. Different evaluation methods have their own specific purposes. Some of them are evaluation of phased learning achievements, others are the evaluation of thinking ability, others are the evaluation of problem-solving ability. Specific ways can be phased and summative examinations, random classroom questions, classroom exercises, academic reports, articles with scientific nature, practical reports and so on. Student achievement assessment is not only a summary of the preceding learning process, but also a comprehensive finding of the problems existing in student achievement and promoting students' all-round development. Evaluate students' achievements from different perspectives. For example, we should carefully investigate and study student achievement and use modern pedagogy, psychology and planning evaluation methods and means to ensure the quality of evaluation, the objectivity and impartiality of science (Zhuang \& Han, 2012). Based on the characteristics of the course content, a multi-level evaluation grade is set up, and the students' innovative learning results are evaluated by classification. A variety of testing methods should be allowed according to the characteristics of the subject. In any form, we should focus on cultivating students' ability to think and evaluate students' ability to acquire knowledge and information.

\section{CONCLUSION}

The cultivation of foreign language talents is one of the key areas of language research, whether foreign or domestic, foreign language researchers have to cultivate talents from different angles, do a lot of research work, and achieved very fruitful results, but there are many shortcomings in the study, and the development of innovative talents is the trend of future development. The cultivation of innovative talents in foreign languages is a complicated systematic project. It requires college administrators and foreign language teachers to take a long-term perspective and understand the essence of the current demand for foreign language talents from the perspective of the times, in order to accurately grasp the core content of foreign language specialty innovation.

\section{REFERENCES}

[1] Huang, Z. D. \& Y. C. Huang. (2016). “A Discussion on the Cultivation of Innovative English Talents.” Foreign Language Teaching 34 (1): 21-25.

[2] Li, H. (2011). "Innovating the Design of Foreign Language Teaching to Promote Autonomous Learning of Adults." Adult Education in China (6): 16-20.

[3] Liu, R. Q. (2015). "The Cultivation of Critical Thinking in Foreign Language Teaching." Adult Education in China (6): 10-12.

[4] Mao, L. Z. \& C. C. Wang. (2011). "An Empirical Study on the Four in One Innovation System of College English.” Higher 
Agricultural Education (2): 21-24.

[5] Niu, A. N. \& S. F. Lu. (2015). "An Practical Research on Innovative Foreign Language Teaching in Europe from the Perspective of Digital Literacy." China Electronic Education (9):10-14.

[6] Sun, Y. Z. \& J. D. Liu. (2013). "Innovating English Assessment System and Leading Students' Development of Thinking Ability." Foreign Languages in China 10 (1): 3-6.

[7] Wang, L. D. (2017). "The Cultivation and Innovation of Translation Talents." Foreign Languages Research (1): 8-12.

[8] Wang, Z. Q. \& L. Ma. (2014). "A Research on Talents Training Mode of Foreign Language Universities in the Context of Globalization -- Take Tokyo Foreign Language University as an Example." Computer-Assisted Foreign Language Education (5): 16-19.

[9] Xia, J. M. (2015). "An Analysis of the Reflection on the Thinking Ability of Foreign Language Teachers in Colleges and Universities." Foreign Languages in China (2): 20-23.

[10] Xie, L. \& L. J. Chang. (2013). "A Discussion on the Cultivation of Innovative Foreign Language Talents in Colleges and Universities." Educational Exploration (7): 14-17.

[11] Xie, X. Y. \& Q. X. Wu. (2013). "Reform and Practice of Foreign Language Practical Teaching Based on Training Objectives of Innovative Talents." Chinese University Teaching (2): 14-17.

[12] Zhuang, Y. L. (2012). "On the Cultivation of Foreign Language Compound Talents." Educational Theory and Practice (6): 16-19.

[13] Zhuang, Z. X. \& H. C. Liu. (2012). “On the Cultivation of a New Type of Foreign Language Talents.” Foreign Language World (2):5-8.

[14] Zhuang, Z. X. \& T. L. Han. (2012). "Reflections on the Training of Internationalized Innovative Talents in Foreign Languages syllabus, curriculum system, teaching methods and means.” Foreign Language World (4):6-9.

Yuan Kong received her M.A. degree in linguistics. She is currently a lecturer at the School of Foreign Languages, Jining Medical University, Jining, Shandong, China. She teaches various subjects including: English intensive reading, English extensive reading, listening, nursing reading and so on. Her research interests mainly include English language teaching, applied linguistics, cross-cultural communication, etc. 